University of Tulsa College of Law

TU Law Digital Commons

Articles, Chapters in Books and Other Contributions to Scholarly Works

2011

\title{
Publishing the Unpublished Correspondence
}

Kevin J.H. Dettmar

William S. Brockman

Robert Spoo

Follow this and additional works at: http://digitalcommons.law.utulsa.edu/fac_pub

Part of the Intellectual Property Commons

\section{Recommended Citation}

49 JAMES JOYCE Q. 143-154 (2011).

This Article is brought to you for free and open access by TU Law Digital Commons. It has been accepted for inclusion in Articles, Chapters in Books and Other Contributions to Scholarly Works by an authorized administrator of TU Law Digital Commons. For more information, please contact daniel-bell@utulsa.edu. 


\title{
NOTES
}

\section{Publishing the Unpublished Correspondence}

\author{
Kevin J. H. Dettmar, William S. Brockman, and Robert Spoo \\ Pomona College, Pennsylvania State University, and University of Tulsa
}

As most readers of the James Joyce Quarterly are well aware, 1 January 2012 marked a watershed moment in modernist literary studies: on that date, all of James Joyce's previously unpublished writing entered the public domain in the United States and many parts of the European Union (having enjoyed that status in Canada and Switzerland since 1992). Among the most significant of these unpublished writings are letters constituting more than half of all of Joyce's known correspondence - at least 1,800 letters, postcards, and telegrams of the 3,594 total known to be extant. ${ }^{1}$ Under the auspices of Oxford University Press, we will be bringing out a three-volume scholarly edition of that previously unpublished correspondence, followed by a one-volume selection for the trade market. The first volume is scheduled for publication in 2017.

Those not intimately familiar with the state of Joyce scholarship are often surprised to learn that more than half of all the known. correspondence written by Joyce is currently unpublished. Many of these letters came to light only after the three-volume standard edition Letters of James Joyce was completed in 1966 (LettersI, II, and III); in addition to these more recently available letters, though, we are eager to make available to scholars previously overlooked letters whose significance has only become clear in the light of new critical approaches to Joyce's writing.

The new edition will modify, nuance, and reveal a great deal about the writer that has to this point remained hidden. Much of the unpublished correspondence, such as the letters in the Paul Léon papers at the National Library of Ireland, casts important light on Joyce as a working writer-a professional writer, paid for his writing, concerned with the fates and fortunes of his work in the modern literary marketplace. As modernist studies have pursued a materialist turn over the past two decades, ${ }^{2}$ sources bearing on these aspects of Joyce's work and thought are increasingly sought after. In 1993, Kevin J. H. Dettmar published an essay in the James Joyce Quarterly grounded in unpublished letters from the Léon papers and showing the care with which Joyce shepherded Ulysses as it made its way in commodity culture; ${ }^{3}$ it is an argument one would never have anticipated and never be able to substantiate, based on the Joyce displayed JJQ, University of Tulsa, 2011. All rights to reproduction in any form are reserved. 
in Richard Ellmann's biography-the writer who, like his writer-protagonist Stephen Dedalus, is presented to us as being "like the God of the creation," remaining "within or behind or beyond or above his handiwork, invisible, refined out of existence, indifferent, paring his fingernails" ( $P$ 215). To give a sense of the range and richness of these letters, we have included sample transcriptions of two of Joyce's unpublished letters to Ezra Pound (10 March 1916, and 1 November 1918). See Appendix 1.

These unpublished letters, postcards, and telegrams reside in a large number of archives: forty-nine different repositories, from the Huntington Library in San Marino, California, to the Staatsbibliothek Preußischer Kulturbesitz, Berlin, and everywhere in between. (For a visualization of the atlas of unpublished Joyce correspondence, see <http://tinyurl.com/cwtgspn>; for a background and a complete listing of the unpublished correspondence, see the recently updated Joyce Calendar at the website listed in endnote 1). The following eight archives house some highlights of the unpublished letters, and suggest some of the richness of these repositories:

\section{Beinecke Library, Yale University:}

Frank Budgen: twenty-four letters from 1919-1940 documenting their friendship.

Ezra Pound: sixty-nine letters providing rich documentation of Pound's support for Joyce's writing, 1913 to 1922 . The EP correspondence tapers off after publication of Ulysses.

\section{British Library, London:}

Harriet Shaw Weaver: 333 unpublished letters; another 119 published by either Stuart Gilbert or Ellmann with deletions. ${ }^{4}$ Both editors worked from copies typed by Weaver. There is extensive documentation of financial matters and Lucia Joyce's illness.

\section{Zurich James Joyce Foundation:}

Giorgio, Helen, and Stephen Joyce: eighty-seven letters and cards primarily from the early 1930s, mixed Italian and English, mostly family matters (including James and Nora's 1931 wedding). They are notable for warmth and intimacy.

Carola Giedion-Welcker: thirty letters, mostly from the 1930s.

\section{New York Public Library:}

Adrienne Monnier: thirty-one letters in French from the 1920s relat- 
ing to the French translation of Ulysses.

John Quinn: twenty-six cards and letters.

National Library of Ireland, Dublin:

Paul Léon: 164 letters mostly from the 1930s pertaining to business and family matters.

\section{Harry Ransom Humanities Research Center, University of Texas, Austin:}

Stuart Gilbert: fifty-five letters dealing with publications, business, and social matters.

Ludmila Bloch-Savitsky: eleven letters on the French translation of A Portrait.

\section{Poetry Collection, University at Buffalo:}

Sylvia Beach and others: thirty-three letters.

\section{Bibliothèque Nationale, Paris:}

Louis Gillet: thirty-seven letters from the 1930s.

We are assembling an international advisory board and, at the time of writing, have secured high-quality digital scans of many unpublished letters from Southern Illinois University Carbondale, the National Library of Ireland, the Zurich James Joyce Foundation, the Houghton Library, and the Northwestern University Library. Much archival travel remains to be undertaken; we intend to have assembled a full library of scans and to begin the work of transcription (verified against originals), translation, and annotation in the summer of 2014.

With this announcement, we invite the participation of private collectors who are in possession of any of Joyce's letters and who therefore have documents that could well represent important primary resources for the understanding of Joyce's life and writings. We can assure collectors that we will respect their wishes regarding the confidentiality of their holdings. While we believe that the contents of any of Joyce's letters could be valuable to researchers, we are prepared to honor the requirements of private collectors who prefer to keep transcriptions from the public eye, and would note in such cases that even the basic details of letters (recipient, date, place, general topic) could be of value. We invite collectors to contact any of us. Mail may be sent to: William Brockman, 329 West Pattee, University Park, PA 
16802, U.S.A. Email users may prefer one of our addresses: Kevin Dettmar: kevin.dettmar@pomona.edu; William Brockman: uxb5@ psu.edu; Robert Spoo: robert-spoo@utulsa.edu.

$* * *$

Call us dreamers, but a three-volume edition of the unpublished correspondence is, potentially, just the tip of the iceberg. The current confused and unsystematic state of the published Joyce correspondence is something of a scandal. ${ }^{5}$ In 1957, Joyce's early champion and popularizer Stuart Gilbert brought out a premature collection of 407 of Joyce's letters (and nineteen letters to Joyce), published by Viking, a trade press (LettersI). The selection process was somewhat opportunistic, with Gilbert, for the most part, publishing all the letters he knew about. He did acknowledge, however, that "[i]t has been a difficult task deciding which of the more intimate letters should be published," and explained that "I have particularly in mind the letters (and they are many) of the last eight years of Joyce's life, relating to the mental breakdown of his daughter [Lucia]" (LettersI 32). He then announced his decision "to make public several of these letters"-suggesting, of course, that others were held back (LettersI 32). The sensitivities of correspondents and family members necessarily affected the edition, and Gilbert wrote that "omissions have been made at the request, always for valid reasons, of those to whom the letters were addressed" (LettersI 39). Other omissions, however, "have been made by the editor; for the most part these affect passages relating to personal and private matters, of no general interest" (LettersI 39). Gilbert's transcriptions contain other lacunae, created when "one comes here and there on words which even those most familiar with [Joyce's] handwriting . . . are unable to decipher. Such words are indicated thus: [Illegible]" (LettersI 39). Finally, although Gilbert wrote that "[f]ootnotes have been added sparingly but, it is hoped, adequately" (LettersI 39), such has not consistently been the verdict of scholars. Letters composed in foreign languages (primarily Italian and French) are presented only in English translation.

Gilbert closed his "Note on the Editing" by stating that "there must certainly be in existence other letters which have not come to the notice of the editor and the publishers: it is to be hoped that owners of such letters will communicate with the publishers, with a view to a second edition of this book or, if enough material comes to light, a second volume. ${ }^{\prime 6}$ In part to address the shortcomings of that debut volume, but more urgently to bring to scholars and students more than a thousand newly discovered letters, Richard Ellmann followed up, in 1966, with two additional volumes (LettersII and III). In his preface, Ellmann wrote: 
Since Stuart Gilbert edited Letters of James Joyce . . . a great many new letters have been found. The two present volumes, numbered $\Pi$ and III, include eleven hundred and thirty-six letters from Joyce, and one hundred and ninety-seven letters from other persons addressed to Joyce or concerned with his affairs. Most of them have only recently become accessible. (LettersII xxvii)

One of the most important caches of letters published in these new volumes was Joyce's correspondence with his patron Harriet Shaw Weaver, though Ellmann had to rely for copy text on Weaver's own typewritten copies, with the manuscripts under seal in the British Museum (now the British Library) until 1971. In making those transcriptions, Weaver "decided to omit" passages-on what grounds, Ellmann did not say-and he was forced to indicate these lacunae with ellipses. ${ }^{7}$ Similarly, many of Ellmann's own transcriptions were made from "photostatic copies," admitting the possibility of various kinds of errors (LettersII xxix). And while Gilbert in 1957 had guessed that "[n]o letters from Joyce to his wife are extant, so far as I can discover," Ellmann included "[s]ixty-two letters written to Nora Barnacle Joyce," though here again family sensitivities prevented him from publishing in unexpurgated versions all the letters to which he had access (LettersI 35, LettersII xxvii). As'a result, two letters that Ellmann described as "written expressly for mutual sexual excitation" were omitted, and eight others suffered "[s]ome cuts" (LettersII xxix). Other pieces of correspondence deemed by Ellmann to be of little scholarly interest-"[a]bout a hundred appointment notes, greeting cards, and other trivial communications" - were omitted (LettersII xxix).

Together these three volumes edited by Gilbert and Ellmann make up The Letters of James Joyce. More than half a century after they began to appear, those mismatched (and long out-of-print) volumes have been supplemented only by Ellmann's 1975 Selected Letters of James Joyce-described as "[ $\mathrm{t}]$ he editor's choice of the best letters from James Joyce's three great volumes, with important additions of previously unpublished letters" (front cover)-and by Melissa Banta and Oscar A. Silverman's 1987 edition of Joyce's correspondence with Sylvia Beach. ${ }^{8}$ Ellmann's Selected Letters added only Joyce's two previously suppressed erotic letters to Nora, along with nine other previously unpublished letters, ${ }^{9}$ though he also used the newly available originals of the Harriet Shaw Weaver correspondence to restore elisions in those letters that he reprinted in the selected edition. Banta and Silverman's James Joyce's Letters to Sylvia Beach added 183 previously unpublished letters and telegrams from that important correspondence. And so today the student or scholar turning to Joyce's correspondence in support of research has access to 1,737 letters, edited by four different scholars (and untold, unnamed assistants), published 
in five different volumes (one volume of which quietly corrects errors and restores omissions in three of the other volumes). ${ }^{10}$

In his preface to the Selected Letters, Ellmann wrote that "[a]n eventual edition of all Joyce's letters, including many not previously known, is contemplated" (SL vii); almost forty years later, however, the community of Joyce scholars and students, as well as students of modernist literature more broadly, is still waiting. With contract in hand from Oxford University Press, we are at work assembling a three-volume edition of previously unpublished letters, postcards, and telegrams. Subject to securing permission from the Joyce Estate and other rights-holders, however, what we would ideally envision is something much bigger: a proper six-volume scholarly edition of all of Joyce's known and obtainable correspondence, including all letters previously published in editions by Gilbert, Ellmann, and Banta and Silverman.

There are many reasons that a reframed six-volume edition of the complete correspondence would be preferable to simply bringing out the unpublished correspondence. As things now stand, a researcher attempting to be thorough must consult five different volumes to look at all of Joyce's published correspondence; by publishing just the unpublished correspondence, we are threatening to bring that total to eight. That would be eight volumes under four different editorial teams and employing slightly differing editorial conventions; four overlapping but differing sets of annotations; four different indices, with no one index incorporating all the correspondence; ${ }^{11}$ and five different sets of overlapping chronological orderings of various subsets of the letters-and with errors and omissions in early volumes being corrected via collation with later volumes. Bringing out the unpublished correspondence will provide a great service to the scholarly community; but without pulling all the correspondence into a uniform scholarly edition, there will undoubtedly continue to be some confusion.

In answer to the possible objections or reservations of rightsholders, there are many good arguments for allowing a complete correspondence edition to go forward. First, no permission is required from, nor would any royalties or fees be owed to, the Estate for an edition of the unpublished correspondence, with distribution confined to the United States and Canada. That material all now exists in the United States and Canadian public domains. But an arrangement might be proposed to the Estate whereby, in exchange for permission to republish (and to a small degree re-edit) the previously published correspondence, royalties or fees could be paid not just on the copyrighted portion of the correspondence but on the entire edition: a "package deal," if you will, that would allow the Estate to benefit from substantial uncopyrighted as well as copyrighted material. This 
could provide an income stream to the Estate when an unpublishedonly edition would provide none. Second, since most of the previously published volumes are currently out of print (and have been for some time: there seems to be no interest on the part of the publishers in reprinting), allowing the previously published correspondence to appear in a new edition would return these non-performing assets of the Estate to the profit column. Third, the prestige of a uniform scholarly edition of the correspondence in six volumes, bearing the imprimatur of Oxford University Press, will, we believe, carry a significance of its own by framing all of the letters within the context of Joyce's correspondence as a whole. Certainly the Press's ongoing edition of The Collected Letters of Thomas Hardy, for instance, suggests that Joyce's correspondence will be done properly and appear in good company. Finally, an authorized complete edition could presumably be distributed in all countries, not just those in which copyrights have expired on unpublished correspondence.

We are braced, however, for the possibility that we will be confined to publishing the unpublished letters in public-domain countries, and we are excited by the prospect of making that signal contribution. The balance of Joyce's correspondence has been relegated too long to the archives. Whereas most of the known letters of Pound to Joyce have been in print for decades, ${ }^{12}$ scores of letters from Joyce to Pound-the other side of that crucial literary collaboration-remain unpublished. Nor would the addition of three more volumes to the constellation of Joyce letters be unprecedented in modernist scholarship. Pound's letters, which are very far from being published in their entirety, are scattered over twenty or more editions, grouped according to friendships, relationships, and associations, and edited with varying degrees of thoroughness. This epistolary jigsaw has challenged Pound scholars, yet it has not prevented productive work from going forward. ${ }^{13}$

We will soon prepare a model set of transcriptions and annotations from a range of Joyce's unpublished correspondence, a selection that will suggest the richness of the unpublished materials and will represent, as well, various periods in Joyce's career and letters from some of his richest sustained correspondences. These transcriptions will then be used as part of an application for a National Endowment of the Humanities Scholarly Editions and Translations Grant.

Much remains to be decided about the ultimate scope of this Joyce editorial project-whether three or six volumes - but at its irreducible core, we will be gathering, transcribing, annotating, and publishing approximately 1,800 previously unpublished pieces of Joyce's correspondence. This material will be of greatest interest to scholars, and, logically, that is where the editorial work has begun. 
Appendix 1: While Joyce's spelling and punctuation have been retained, we have standardized the format by aligning recurrent elements (such as return addresses and dates) and by incorporating Joyce's marginal and interlineal insertions into the body of his text.

\title{
To Ezra Pound, 10 March 1916, ALS: Beinecke Library
}

This letter shows Joyce simultaneously striving for publication of $A$ Portrait and Exiles, in the early stages of writing Ulysses, and troubled by one of the eye ailments that plagued him for much of his life.

Kreuzstrasse 19 ir Zurich VIII (Switzerland)

My dear Pound: I have been suffering rather badly from an attack of rheumatism which I have succeeded in keeping out of my eyes so far. Miss Weaver writes that Mr Pinker has not yet drawn up the agreement. I have written to him instructing him to do so at once and to her informing her that if he does not I shall send her a blank signed agreement which he can fill in later at her dictation. As regards terms I have instructed him to accept unconditionally, subject to his commission, whatever terms she is able to propose. She writes that four printing firms have refused to print my novel. One (Messrs Clay and Sons) accepted at first and then refused. She writes also that an ex-clerk of Messrs Maunsel and Co of Dublin who, it seems, is now in the employment of The Egoist informs her that if my book is not published before 1 April (All Fools' Day) it cannot be published this spring. Possibly he can say also who paid the Irish printer, Falconer, and for $£ 70$ to burn the first edition of my book of stories. I confess that I find the re-emergence of this name a bad omen.

Mr Pinker, I presume, is still "doing his best" with the verses and the play I sent him. If a printer is found and time is limited would you read the proofs for me? In return if you like I shall correct the proofs of your next book. If you cannot I suggest that some reader be found and the fee charged to me. In any case I want the book to be published this spring as, until it is out of the way, I cannot continue what I am writing. I had just begun again and now this bad news comes to obstruct me. I am sending this letter express to your address in London to save time. Have you any news from Poetry or from Drama? I hope that if your article has appeared in the latter review it may be possible for you to print my play when you become editor of your new review. I hope (not only for my sake) that its prospects are still good. I hope also that you are in good health. I wish I could say as much for myself. I could scarcely walk last week but I do not care so long as I do not get a relapse of iritis. Today I feel much better. Perhaps it is due to the stimulus of this bad news.

\author{
With very kind regards \\ sincerely yours \\ James Joyce \\ 10 March 1916
}


Two years later, A Portrait and Exiles had been published (in 1916 and 1918, respectively), Joyce was well into the composition of Ulysses (which had already begun serial publication in The Little Review) and was seeking to have Exiles produced on-stage. Even at this early point, he was considering a French printer for the eventual book version of Ulysses.

Universitätsstrasse 29 III Zurich (Switzerland)

Dear Pound: I hope you are not ill with this bad epidemic as it is a long time since I heard from you. I am glad to say we are all well and I trust all with you are the same. The above is my new address. It was rather difficult to find quarters but luckily (through my milkman) I got rooms in the same street.

I sent you lately the 8th episode (Lestrygonians) and before that the 7th (Eolus) but have had no acknowledgement of receipt. Miss Weaver wrote lately and said that she had not received this episode from you. I hope to be able to send you the ninth episode (Scylla and Charybdis) shortly. Enclosed are some extra press notices of my former book. Molto fumo e poco arrosto for only 40 copies seem to have been sold this year. I should be pleased to receive from you copies of the Little Review for August, September and October. I hope the chapters have appeared intact.

I sent you also a presentation copy of Exiles which I hope you got. I wrote once or twice to Yeats and to Mr Sturge Moore about its production but have received no reply. My agent (at my request) sent copies also to Pioneer Players and to Miss Horniman. No reply. I have heard nothing from my publisher in New York either as to the sales of this book or the press notices in America or its production there. I should like to put the play into the hands of some active agent. A Mr Marion L Bloom wrote to me a long time ago but my illness made me forget his proposal. The name is rather curious, is it not? But so many of these strange coincidences happen. Whether he would like to take on the representation for Ulysses is I suppose doubtful. Messrs Crès and $\mathrm{Co}$, Boul' S. Germain have placed their printer at the disposal of my publisher whoever or wherever he be when and if Ulysses is published.

Miss Weaver wrote that a Mr Fels wanted to do a French translation. It will appear I presume together with Mr Davray's article. I wrote also to Mr Linati about an Italian version and a Miss Maag wrote about a Danish translation. I had also a letter from Mr George Brandes asking for a copy of the book. I had none to send him.

My delay in sending you Exiles is due to the slowness of my publisher in forwarding copies. But perhaps transit of books is long and difficult. I think you do not admire the play but perhaps you will accept it in the way I mean it.

With kind regards to Mrs Pound and yourself from us all and best wishes for your continued good health.

sincerely yours

James Joyce

$1 / \mathbf{x i} / 918$ 
P.S. I have received a letter from a Mr Owen Nugent, 2 Carnmore Terrace, Whiterock Road, Belfast. He has read the first episode of Ulysses and likes it. If you send him a copy of the second perhaps he may wish to subscribe to your review. I think he may if he is not already a subscriber.

J.J.

\section{NOTES}

${ }^{1}$ More than a year into the project, we are keenly aware of how approximate these numbers are: visits to archives have uncovered much previously unknown correspondence. The Joyce Calendar-<http://norman.hrc.utexas.edu/JamesJoyceChecklist/calendar.cfm $>$-now provides an up-to-date account of what is known to be extant, and we are hopeful, too, of gaining access to some correspondence in private hands.

2 See, for instance, Kevin J. H. Dettmar and Stephen Watt, eds., Marketing Modernisms: Self-Promotion, Canonization, and Rereading (Ann Arbor: Univ. of Michigan Press, 1996).

3 See Dettmar, "Selling Llysses," JJQ, 30 (Summer-Fall 1993), 795-812. In Without Copyrights: Piracy, Publishing, and the Public Domain (New York: Oxford Univ. Press, forthcoming July 2013), Robert Spoo draws extensively on the letters of Joyce and other writers to show the impact of copyright laws, the American public domain, and informal publishing norms on transatlantic modernism.

${ }^{4}$ See JIII and LettersI.

5 The publication history of Joyce's correspondence is given in detail in William S. Brockman, "Letters," James Joyce in Context, ed. John McCourt (Cambridge: Cambridge Univ. Press, 2009), pp. 27-38.

${ }^{6}$ See Stuart Gilbert, Letters of James Joyce (New York: Viking Press, 1957), p. 41. The quoted text was omitted from the 1966 reprinting.

${ }^{7}$ Revisiting the question in 1975, Ellmann wrote that the deletions "were needed principally because of her sympathy for Joyce, her modesty about her own role in his life, and her reluctance to consider money matters important" (SL viii).

${ }^{8}$ Melissa Banta and Oscar A. Silverman, eds., James Joyce's Letters to Sylvia Beach, 1921-1940 (Bloomington: Indiana Univ. Press, 1987).

${ }^{9}$ While, in the first paragraph of the preface, Ellmann claimed that the Selected Letters compilation contains "ten letters not published before," in the following three paragraphs he went on to identify eleven: two to Lady Gregory; one to Ezra Pound; one to Stanislaus Joyce; two to Nora Joyce; and five to Harriet Shaw Weaver (p. vii).

10 This census does not account for letters published in full or in part in periodicals, catalogs, or other selective venues.

11 We do intend, however, to index the previously published volumes as part of our edition.

12 See Forrest Read, ed., Pound/Joyce: The Letters of Ezra Pound to James Joyce (New York: New Directions, 1967), and Spoo, "Unpublished Letters of Ezra Pound to James, Nora, and Stanislaus Joyce," JJQ, 32 (Spring-Summer 1995), 533-81.

${ }^{13}$ One of us has contributed to that jigsaw. See Omar Pound and Spoo, 
eds., Ezra and Dorothy Pound: Letters in Captivity, 1945-1946 (New York: Oxford Univ. Press, 1999), and Pound and Spoo, eds., Ezra Pound and Margaret Cravens: A Tragic Friendship 1910-1912 (Durham, N.C.: Duke Univ. Press, 1988).

\section{Closing Time: "ten minutes to ten" and the End of Childhood in Joyce's "Araby"}

\section{Steven Doloff \\ Pratt Institute}

Teyward Ehrlich identifies what he finds to be a "little puzzle" Inear the end of James Joyce's story "Araby" regarding "why Joyce fixes the time of the boy's arrival at the bazaar at exactly 9:50 P.M., even though other events in the story are only given approximate times."1 Ehrlich's solution to the puzzle is that, by having his young protagonist specify "the lighted dial of a clock" showing "ten minutes to ten" (D 34), Joyce is evoking, as part of an Irish Orientalist motif in the story, a "tradition of Arabic ciphers, which use letters of the alphabet and individual numbers as substitutes for each other" (326). Ehrlich continues, "If we regard 'ten' as a cipher in the Latin alphabet, we obtain the letter ' J,' and for two tens we get ' $\mathrm{JJ}$,' Joyce's initials" (326).

I offer another solution to this puzzle but one that references the main character rather than the author. As Ehrlich states, we are invited to imagine "the position of the hour and minute hands ... perfectly superimposed" (326). While clock hands regularly meet twenty-four times during the course of a day, their particular occurrence at 9:50 P.M. at the end of "Araby" may have a special contextual significance. Their juncture immediately precedes the boy's anguished selfrevelation and what appears to be the near-simultaneous closing of the bazaar at ten o'clock. If we choose to see the longer minute hand of the clock as representing adulthood and the shorter one childhood, then "ten minutes to ten" would symbolically portend the moment that adulthood overtakes the boy's childhood, eclipses it, and begins to leave it behind-a simple visual icon for a widely acknowledged theme in the story.

This diagrammatic reading of a maturative passage implied by the rotating clock hands may, in fact, find a kind of corroborating visual analog in the next act the boy performs, virtually at the same moment as "ten minutes to ten." He looks from the clock to the bazaar and reports, "I could not find any sixpenny entrance and, fearing that the bazaar would be closed, I passed in quickly through a turnstile, handing a shilling to a weary-looking man" (D 34).

William Burto notes the boy's inability to find a child's sixpenny 
entrance, which forces him to use the general-admission shilling turnstile into the bazaar and anticipates the similarly imposed "adult" perspective on himself waiting inside. ${ }^{2}$ While, it seems, no evidence either from the 1904 bazaar itself or Joyce's recreation of it indicates the actual or fictional existence of such a cheaper entrance, the loss of this juvenile privilege in the character's mind, like the clock hands, foreshadows his greater disappointment soon to follow. Indeed, the turnstile serves visually to reiterate the clock face's symbolic rotational delivery of the boy to the end of his childhood.

As Ezra Pound observes in The Egoist in 1914, "Araby ... is a vivid waiting, ${ }^{\prime 3}$ since the boy literally stares at a clock and listens to it tick before he leaves for the bazaar $(D 33)$. In fact, the story contains several different instances of implicit or explicit waiting, starting with its opening sentence: "North Richmond Street, being blind, was a quiet street except at the hour when the Christian Brothers' School set the boys free" (D 29). The anticipated rewards of these vigils for the protagonist of "Araby" are youthful ones: liberation from school, the joyful sight of Mangan's sister-“"Every morning I lay on the floor in the front parlour watching her door. ... When she came out on the doorstep my heart leaped" (D 30)—and, finally, the planned purchase of the boy's pledged gift for her from the bazaar.

But the salutary promise of time for Joyce's immature protagonist, after his perusal of the "ten minutes to ten" clock face, turns, in both visual and psychological terms, to a rotary of disappointment and, arguably, into one of the many cyclical correlatives of futility and paralysis found throughout Dubliners.

\section{NOTES}

${ }^{1}$ See Heyward Ehrlich, "'Araby' in Context: The 'Splendid Bazaar,' Irish Orientalism, and James Clarence Mangan," JJQ, 35 (Winter-Spring 1998), 326. Further references will be cited parenthetically in the text.

${ }^{2}$ See William Burto, "Joyce's 'Araby,'” Explicator, 25 (April 1967), Item \#67, n.p. "Obviously," Burto says, "the sixpenny gate is for children. Unable to locate it ... the boy is forced to enter by the shilling (adult) turnstile. $\mathrm{He}$ enters, and leaves, a man, or at least further on the road to manhood."

${ }^{3}$ Ezra Pound, "'Dubliners' and Mr. James Joyce," The Egoist, 1 (15 July 1914), 267, and reprinted in Literary Essays of Ezra Pound, ed. T. S. Eliot (1968; Westport, Conn.: Greenwood Press, 1979), p. 400. 